\title{
EFEKTIVITAS MODEL PEMBELAJARAN APTITUDE TREATMENT INTERACTION (ATI) DAN TEAM ASSISTED INDIVIDUALIZATION (TAI) TERHADAP HASIL BELAJAR
}

\author{
Reza Bagindo ${ }^{1}$, Putri Yulia*2 \\ ${ }^{1}$ Universitas Riau Kepulauan, Batam, Kepulauan Riau \\ ${ }^{2}$ Institut Agama Islam Negeri (IAIN) Kerinci \\ *Email: putriyuliamz@gmail.com
}

\begin{abstract}
Abstrak. Tujuan penelitian ini adalah mengetahui efektivitas model pembelajaran ATI dan TAI terhadap hasil belajar siswa kelas VII SMPN 10 Batam. Penelitian ini merupakan jenis penelitian quasi experimental dengan Pretest-Posttest Control Group Design. Populasi pada penelitian ini adalah seluruh siswa kelas VII SMPN 10 Batam, dengan sampel siswa kelas VII 1 dan VII 2. Instrumen yang digunakan adalah soal pretest dan posttest hasil belajar matematika. Teknik analisis data yang digunakan adalah uji-T satu sampel untuk hipotesis 1 dan 2 serta uji-T polled varians untuk hipotesis 3 dengan taraf keyakinan 5\%. Hasil penelitian menunjukkan bahwa: (1) Model pembelajaran ATI efektif terhadap hasil belajar siswa kelas VII SMPN 10 Batam, (2) Model pembelajaran TAI efektif terhadap hasil belajar siswa kelas VII SMPN 10 Batam, dan (3) Terdapat perbedaan efektivitas model pembelajaran ATI dan TAI terhadap hasil belajar siswa kelas VII SMPN 10 Batam.
\end{abstract}

Kata kunci: Model pembelajaran ATI, Model Pembelajaran TAI, Hasil belajar siswa.

\begin{abstract}
The purpose of this study is to identify the effectiveness of ATI learning model and TAI learning model toward the result of the study of students grade VII at SMPN 10 Batam. The research was quasi experimental with Pretest-Posttest control group design. The population of the research was all the students grade VII at SMPN 10 Batam and the sample were the students of class VII 1 and VII 2. The instrument which was used mathematic pretest and posttest of the result of the study. Technique of data analysis which was used one sample t-test for hypothesis for 1 and 2, and polled varians t-test for hypothesis 3 with a significance level 5\%. The result of the study showed that: (1) ATI learning model is effective toward the result of the study of students grade VII at SMPN 10 Batam, (2) TAI learning model is effective toward the result of the study of students grade VII at SMPN 10 Batam, (3) There are differences of the effectiveness of ATI and TAI teaching model toward the result of the study of students grade VII at SMPN 10 Batam.
\end{abstract}

Keywords : ATI Learning Model, TAI Learning Model, The Result Of The Study, Education.

\section{Pendahuluan}

Pendidikan merupakan sesuatu yang sangat penting bagi bangsa dan Negara. Selain itu dunia pendidikan juga tidak kalah perannya dalam meningkatkan kemajuan suatu bangsa. Sebagaimana yang telah diatur Depdiknas (2003) dalam Undang-Undang Nomor 20 tentang Sistem Pendidikan Nasional yang menyatakan bahwa: "Pendidikan adalah usaha sadar dan terencana untuk mewujudkan suasana belajar dan proses pembelajaran agar siswa secara aktif mengembangkan potensi dirinya untuk memiliki kegiatan spiritual keagamaan, pengendalian diri, kepribadian, kecerdasan, akhlak mulia, serta keterampilan yang diperlukan dirinya, masyarakat dan Negara".

Menurut Russefendi (dalam Suwangsih \& Tiurlina, 2006:4) matematika terorganisasikan dari unsur-unsur yang tidak didefinisikan, definisi-definisi, aksioma-aksioma dan dalil-dalil dimana dalil-dalil setelah dibuktikan kebenarannya berlaku secara umum, karena itulah matematika sering disebut ilmu deduktif". 
Namun, kenyataan yang diperoleh saat peneliti melakukan Praktek Lapangan di SMPN 10 Batam tepatnya pada bulan Agustus sampai Desember di kelas VII masih menujukkan banyaknya permasalahan yang dialami baik oleh siswa maupun guru. Salah satunya yaitu kurangnya minat siswa dalam belajar terlebih lagi untuk mata pelajaran matematika. Hal ini disebabkan karena berlebihnya kapasitas jumlah siswa yang ada di dalam satu ruangan kelas yaitu berkisar antara 46-48 siswa. Padatnya jumlah siswa sangat berpengaruh besar terhadap proses maupun hasil belajar siswa.

Materi yang rumit ditambah dengan banyaknya rumus yang harus dihafalkan membuat siswa menjadi semakin malas untuk belajar apalagi dalam suasana kelas yang menegangkan. Banyaknya persepsi negatif mengenai pembelajaran matematika juga berdampak pada minat belajar siswa. Akibatnya, siswa pun menjadi tidak aktif ketika pembelajaran sedang berlangsung dan sebagian besar dari mereka juga enggan untuk bertanya seputar materi yang belum mereka pahami.

Banyak hal yang bisa dilakukan sekolah dan guru dalam mengatasi rendahnya hasil belajar siswa. Misalnya dengan adanya penerapan model pembelajaran yang kreatif dan inovatif. Saat ini, berbagai macam model pembelajaran semakin banyak dikembangkan oleh para ahli salah satunya yaitu dengan adanya model pembelajaran kooperatif. Model ini lebih menekankan pada cara belajar yang terdiri dari suatu kelompok di mana siswa saling bekerja sama untuk memecahkan setiap persoalan atau tugas yang diberikan guru. Di dalam pembelajaran kooperatif, keaktifan siswa dalam mengeluarkan pendapat sangat diutamakan. Selain itu, pembelajaran dengan model kooperatif juga dapat menciptakan suasana ruang kelas yang terbuka karena pembelajaran ini mampu membangun keberagaman dan mendorong koneksi berpikir antarsiswa. Maka, dengan menggunakan model kooperatif hasil belajar siswa sangat diperhatikan agar mencapai ketuntasan yang diinginkan.

Berdasarkan berbagai macam permasalahan di atas, maka diperlukan suatu model pembelajaran yang dapat merangsang motivasi belajar dan keaktifan siswa yaitu model pembelajaran Aptitude Treatment Interaction (ATI) dan model pembelajaran Team Assisted Individualization (TAI). Model Pembelajaran ATI menurut Syafruddin (dalam Siahaan, 2016:8) secara substantif dan teoritik, dapat diartikan sebagai suatu konsep atau pendekatan yang memiliki sejumlah strategi pembelajaran (treatment) yang efektif digunakan untuk individu sesuai dengan kemampuan (aptitude) masing-masing. Sedangkan dasar pemikiran dari dibentuknya model pembelajaran TAI ini menurut Slavin (2005:187) adalah untuk mengadaptasi pengajaran terhadap perbedaan individual berkaitan dengan kemampuan siswa maupun pencapaian prestasi/hasil belajar siswa.

Model pembelajaran ATI dan TAI juga dirancang untuk meningkatkan hasil belajar siswa. Dengan adanya penerapan cara belajar secara berkelompok tentu akan meminimalisir terjadinya kesulitan siswa dalam menyelesaikan suatu soal. Beberapa kelebihan kedua model pembelajaran ini adalah sama-sama dapat meningkatkan hasil belajar siswa, dapat merangsang motivasi belajar siswa, dapat membantu siswa yang lemah, siswa diajarkan cara bekerja sama dalam suatu kelompok dan terbentuknya rasa tanggung jawab siswa dalam kelompoknya.

Berdasarkan latar belakang di atas, maka peneliti tertarik untuk melakukan penelitian dengan judul "Efektivitas Model Pembelajaran Aptitude Treatment Interaction (ATI) dengan Team Assisted Individualization (TAI) Terhadap Hasil Belajar Siswa Kelas VII SMPN 10 Batam".

\section{Metode Penelitian}

Jenis penelitian yang digunakan dalam penelitian ini adalah penelitian kuantitatif. Metode penelitian ini menggunakan penelitian kuasi eksperimen. Sedangkan desain penelitian menggunakan rancangan Pretest-Posttest Only Control Group Design (Lubis, 2013:31). 
Populasi dalam penelitian ini adalah seluruh siswa kelas VII SMPN 10 Batam Tahun Ajaran 2016/2017 yang terdiri dari 10 kelas dengan jumlah siswa sebanyak 472 orang. Teknik pengambilan sampel pada penelitian ini yaitu dengan menggunakan Cluster Random Sampling. Menurut Arikunto (2016:174) teknik sampling ini digunakan untuk menentukan sampel jika objek/subjek yang akan diteliti sangat luas. Selanjutnya, peneliti melakukan pengambilan dua kelas secara acak dengan terpilihnya kelas VII 1 sebagai kelas eksperimen 1 dan kelas VII 2 sebagai kelas eksperimen 2. Penelitian ini dilakukan pada bulan April sampai bulan Mei 2017. Variabel bebas pada penelitian ini adalah model pembelajaran ATI $\left(X_{1}\right)$ dan model pembelajaran TAI $\left(X_{2}\right)$. Sedangkan untuk variabel terikat pada penelitian ini adalah hasil belajar matematika siswa kelas VII SMPN 10 Batam $(Y)$.

Untuk mengetahui hasil belajar siswa, pada kedua kelas eksperimen diberikan tes berupa pretest dan posttest. Pemberian pretest dilakukan untuk mengetahui kemampuan awal siswa pada kedua kelas eksperimen sebelum diberikannya perlakuan. Sedangkan pemberian posttest dilakukan untuk melihat sejauh mana hasil belajar yang diperoleh setelah diberikan perlakuan.

Teknik pengumpulan data yang digunakan pada penelitian ini yaitu dengan menggunakan tes. Tes digunakan untuk melihat sejauh mana perkembangan hasil belajar matematika siswa setelah nantinya diberikan perlakuan pada masing-masing model pembelajaran dengan pretest sebanyak 7 soal dan posttest sebanyak 7 soal pula.

Untuk teknik analisis instrumen dalam penelitian meliputi validitas, tingkat kesukaran, daya pembeda dan reliabilitas. Sementara untuk validitas juga dilakukan dengan menguji validitas isi dan kontsruknya. Pada validitas isi, hasil diperoleh dari penilaian ahli (expert jugdement) dengan melibatkan 3 orang ahli diantaranya 2 orang ahli dari dosen pendidikan matematika dan 1 orang ahli dari guru SMPN 10 Batam. Kriteria yang digunakan pada validitas isi meliputi essensial, berguna tapi tidak essensial dan tidak layak digunakan (Heri, 2016:5). Dan untuk validitas kontruk, hasil diperoleh dengan menggunakan rumus korelasi productmoment (Lestari \& Yudhanegara, 2015:193). Hasilnya diperoleh untuk soal pretest terdapat 7 soal yang valid dan soal posttest diperoleh 6 soal yang valid. Pada hasil uji tingkat kesukaran, diperoleh untuk soal pretest dan posttest memiliki tingkat kesukaran yang sedang dan mudah. Daya pembeda untuk soal pretest diperoleh dengan kriteria buruk dan cukup, sedangkan soal posttest diperoleh daya pembeda berkriteria sangat baik, baik dan cukup. Uji reliabilitas pada penelitian ini yaitu dengan menggunakan rumus Alpha Cronbach (Arikunto, 2016:239).

Teknik analisis data yang dilakukan yaitu uji keseimbangan, uji normalitas dan uji homogenitas. Uji keseimbangan dilakukan agar peneliti dapat memperoleh kesimpulan jika prosedur suatu sampel telah memiliki kemampuan awal yang sama. Selanjutnya yaitu dengan melihat uji normalitas yang meggunakan uji statistik kolmogorov-smirnov dengan bantuan SPSS statistic 20. Teknik analisis data yang selanjutnya dilakukan yaitu uji homogenitas data pretest dengan menggunakan rumus uji $\mathrm{F}$. Untuk uji hipotesis 1 dan 2 yang dilakukan pada penelitian ini yaitu menggunakan rumus one sample t-test dan untuk uji hipotesis 3 menggunakan rumus polled varians dengan taraf signifikan sebesar 5\%

\section{Hasil Penelitian Dan Pembahasan}

Langkah awal dalam penelitian ini adalah peneliti akan menguji kemampuan awal siswa pada setiap kelas. Data yang digunakan yaitu dengan menggunkan pretest yang diberikan sebelum pembelajaran dilaksanakan. Adapun data-data tersebut dapat dideskripsikan sebagai berikut: 
Tabel 1. Data Hasil Pretest

\begin{tabular}{lcc}
\hline \multirow{2}{*}{ Deskripsi Data } & \multicolumn{2}{c}{ Pretest } \\
\cline { 2 - 3 } & Eksperimen 1 & Eksperimen 2 \\
\hline Rata-rata & 56,956 & 55,021 \\
$\boldsymbol{S}$ & 5,321 & 5,780 \\
$\boldsymbol{S}^{\mathbf{2}}$ & 28,313 & 33,418 \\
Skor Tertinggi & 68 & 67 \\
Skor Terendah & 47 & 42 \\
Skor Ideal Tertinggi & 100 & 100 \\
Skor Ideal Terendah & 0 & 0 \\
Jumlah Siswa & 45 & 46 \\
\hline
\end{tabular}

Sebelum dilakukan uji keseimbangan, terlebih dahulu dilakukan uji normalitas untuk mengetahui apakah data tersebut berdistribusi normal atau tidak. Pengolahan data dilakukan dengan menggunakan uji Kolmogorov-Smirnov berbantuan SPSS statistics 20. Hasil dari uji normalitas dapat dilihat pada tabel berikut:

Tabel 2. Hasil Uji Normalitas Pretest

\begin{tabular}{lcccc}
\hline & \multicolumn{3}{c}{ Kolmogorov-Smirnov $^{\text {a }}$} \\
\cline { 2 - 5 } & Statistic & df & Sig. \\
\hline Eksperimen 1 & .106 & & 45 & $.200^{*}$ \\
Eksperimen 2 & .091 & 46 & $.200^{*}$ \\
\hline
\end{tabular}

Berdasarkan tabel di atas, diperoleh nilai signifikan dari kedua kelas eksperimen sebesar 0,200 > 0,05 dan $H_{0}$ diterima. Jadi dapat disimpulkan bahwa data pretest dari kedua kelas eksperimen berdistribusi normal. Kemudian dilakukan uji homogenitas untuk mengetahui apakah data berasal dari populasi yang bervariansi sama (homogen) atau tidak di mana rumusnya menggunakan uji F. Diperoleh hasil dari $F_{\text {hitung }}=1,18$ dan $F_{\text {tabel }}=1,92$. Karena $F_{\text {hitung }}<F_{\text {tabel }}$ maka disimpulkan bahwa kemampuan awal kedua kelas eksperimen memiliki variansi yang homogen.

Setelah itu barulah dilakukan uji keseimbangan pada kedua kelas eskperimen untuk mengetahui kemampuan awal siswa. Uji keseimbangan dilakukan dengan menggunakan uji-t dua sampel. Hasil yang diperoleh yaitu nilai signifikan $=0,089>0,05$ dan $H_{0}$ diterima. Jadi, dapat disimpulkan bahwa kedua kelas eksperimen memiliki kemampuan awal yang sama.

Setelah diberikannya perlakuan pada kelas eksperimen 1 dengan menggunakan model pembelajaran ATI dan kelas eksperimen II dengan menggunakan model pembelajaran TAI maka dapat dilihat hasil posttest pada tabel berikut:

Tabel 3. Data Hasil Posttest

\begin{tabular}{lcc}
\hline \multirow{2}{*}{ Deskripsi Data } & \multicolumn{2}{c}{ Posttest } \\
\cline { 2 - 3 } & Eksperimen 1 & Eksperimen 2 \\
\hline Rata-rata & 78,681 & 71,195 \\
$\boldsymbol{S}$ & 11,721 & 12,952 \\
$\boldsymbol{S}^{\mathbf{2}}$ & 137,384 & 167,761 \\
Skor Tertinggi & 97 & 93 \\
Skor Terendah & 53 & 50 \\
Skor Ideal Tertinggi & 100 & 100 \\
Skor Ideal Terendah & 0 & 0 \\
Jumlah Siswa & 44 & 41 \\
\hline
\end{tabular}


Berdasarkan tabel 3 di atas yang diperoleh dari hasil olah data statistik, maka terlihat bahwa rata-rata skor posttest kelas eksperimen 1 yang mendapatkan perlakuan dengan menggunakan model pembelajaran ATI lebih tinggi dari pada kelas eksperimen 2 yang mendapatkan perlakuan dengan menggunakan model pembelajaran TAI.

Sebelum data dianalisis untuk menguji hipotesis, maka data tersebut harus memenuhi syarat normal dan homogen. Data yang digunakan diperoleh dari hasil posttest yang diberikan setelah perlakuan pada kelompok sampel telah dilakukan. Setelah mendapatkan data dari hasil posttest, maka dilakukan uji normalitas dilakukan dengan menggunakan uji statistik Kolmogorov-Smirnov berbentuan software SPSS statistics 20. Adapun hasil dari uji normalitas dapat dilihat pada tabel berikut:

Tabel 4. Hasil Uji Normalitas Posttest

\begin{tabular}{lcccc}
\hline & \multicolumn{4}{c}{ Kolmogorov-Smirnov $^{\text {a }}$} \\
\cline { 2 - 5 } & Statistic & df & Sig. \\
\hline Eksperimen 1 & .108 & 44 & $.200^{*}$ \\
Eksperimen 2 & .101 & 41 & $.200^{*}$ \\
\hline
\end{tabular}

Berdasarkan tabel di atas, diperoleh nilai signifikan dari kedua kelas eksperimen sebesar $0,200>0,05$ dan $H_{0}$ diterima. Jadi dapat disimpulkan bahwa data posttest dari kedua kelas eksperimen berdistribusi normal.

Setelah uji normalitas, maka dilakukan uji homogenitas dengan cara membandingkan variansi dari data hasil posttest antara kelas eksperimen 1 dan kelas eksperimen 2 dengan menggunakan uji F. Diperoleh hasil dari $F_{\text {hitung }}=1,22$ dan $F_{\text {tabel }}=1,92$. Karena $F_{\text {hitung }}<$ $F_{\text {tabel }}$ maka disimpulkan bahwa haisl posttest kedua kelas eksperimen memiliki variansi yang homogen.

Pada Hipotesis 1, Sebelum dilakukannya perhitungan dengan menggunakan rumus one sample t-test, terlebih dahulu mencari $\mu_{0}$ atau nilai rata-rata yang dihipotesiskan dengan nilai $\mu_{0}=68,33$. Kemudian untuk nilai $t_{\text {hitung }}=5,858$ dan $t_{\text {tabel }}=1,680$ dengan taraf signifikan 5\%. Karena $t_{\text {hitung }}>t_{\text {tabel }}$ maka $H_{0}$ ditolak dan $H_{a}$ diterima. Jadi, dapat disimpulkan bahwa model pembelajaran ATI efektif terhadap hasil belajar siswa kelas VII SMPN 10 Batam.

Di dalam penelitian ini, kelas eksperimen 1 diberikan perlakuan (treatment) dengan menggunakan model pembelajaran ATI. Model pembelajaran ATI merupakan suatu model pembelajaran yang cara belajarnya menggunakan kelompok. Dengan adanya pembelajaran secara berkelompok, maka siswa pun bisa lebih aktif untuk berdiskusi dengan sesama anggota kelompoknya.

Sebelum dimulainya pembelajaran dengan menggunakan model ATI, peneliti terlebih dahulu menyampaikan tujuan dan langkah-langkah pembelajaran dengan menggunakan model ini. Perlakuan yang diberikan pada setiap kelompok juga tidaklah sama. Untuk kelompok siswa dengan kemampuan tinggi diberikan pembelajaran melalui modul yang telah disiapkan peneliti. Untuk kelompok siswa dengan kemampuan sedang diberikan perlakuan dengan cara regular teaching dan untuk kelompok siswa berkemampuan rendah diberikan pembelajaran dengan cara regular teaching ditambah dengan tutorial. Untuk pelaksanaan tutorial sendiri, diberikan pada jam kosong setelah pembelajaran selesai. Pada pertemuan pertama, peneliti masih kesulitan untuk menerapkan model pembelajaran ATI dikarenakan kondisi kelas yang belum sepenuhnya dapat terkontrol dengan baik. Kemudian pada pertemuan berikutnya kelas sudah mulai bisa terkontrol dengan baik dan siswa pun mulai bisa belajar secara berkelompok. Materi yang diajarkan adalah mengenai sudut, karena pada 
pembelajaran dengan menggunakan model ini selalu dikaitkan dengan dunia nyata, maka siswa pun menjadi lebih aktif untuk bertukar pikiran dengan sesama teman anggota kelompoknya. Model pembelajaran ATI memberikan hasil yang efektif terhadap hasil belajar matematika siswa kelas VII SMPN 10 Batam. Hal ini sejalan dengan penelitian yang dilakukan oleh Widiastuti (2014) yang menyimpulkan model pembelajaran ATI dapat meningkatkan hasil belajar siswa.

Pada Hipotesis 2, sebelum juga dilakukannya perhitungan dengan menggunakan rumus one sample t-test, terlebih dahulu mencari $\mu_{0}$ atau nilai rata-rata yang dihipotesiskan nilai $\mu_{0}=63,61$. Kemudian untuk nilai $t_{\text {hitung }}=3,750$ dan $t_{\text {tabel }}=1,682$ dengan taraf signifikan $5 \%$. Karena $t_{\text {hitung }}>t_{\text {tabel }}$ maka $H_{0}$ ditolak dan $H_{a}$ diterima. Jadi, dapat disimpulkan bahwa model pembelajaran TAI efektif terhadap hasil belajar siswa kelas VII SMPN 10 Batam.

Di dalam penelitian ini, kelas eksperimen diberikan pembelajaran dengan menggunakan model TAI. Pada pelaksanaannya, model pembelajaran TAI juga menggunakan kelompok belajar yang dibagi secara heterogen. Tujuannya agar pembelajaran menjadi lebih aktif dan siswa bisa mudah bertukar pikiran dengan sesama anggota kelompoknya. Pada pertemuan pertama, peneliti menjelaskan mengenai tujuan pembelajaran yang akan dicapai. Kemudian, pembagian kelompok siswa pada pertemuan pertama didasarkan pada hasil dari nilai ulangan sebelumnya. Akan tetapi, untuk pertemuan kedua sampai keempat pembagian kelompok didasarkan pada hasil dari kuis individu yang diberikan setiap akhir pembelajaran.

Setelah pembagian kelompok selesai, peneliti mulai menerapkan cara pembelajaran dengan menggunakan model pembelajaran TAI. Di pertemuan pertama siswa juga masih kaku dan belum terbiasa dengan pembelajaran yang dilakukan secara bekelompok. Pada pertemuan berikutnya, pembelajaran pun menjadi lebih terarah karena siswa sudah mulai bisa mengikuti pembelajaran secara berkelompok. Setiap anggota kelompok juga mulai berdiskusi dan saling bertukar pikiran mengemukakan pendapatnya masing-masing. Peneliti juga memberikan reward kepada setiap kelompok yang unggul dalam pembelajaran. Tujuannya adalah untuk meningkatkan motivasi siswa dalam setiap pembelajaran.

Di dalam model pembelajaran ini, guru hanya bertindak sebagai fasilitator yang artinya siswa lebih dituntut aktif dalam pembelajaran. Model pembelajaran TAI memberikan hasil yang efektif terhadap hasil belajar matematika siswa kelas VII SMPN 10 Batam. Hal ini sejalan dengan penelitian yang dilakukan oleh Haris (2015) yang menyimpulkan bahwa dengan menggunakan model TAI hasil belajar siswa menunjukkan peningkatan pada pra siklus I sebesar 61,2 menjadi 71 pada pra siklus II. Sedangkan untuk rata-rata hasil belajar menunjukkan peningkatan sebesar 73.

Pada Hipotesis 3, Seperti yang diketahui bahwa data posttest dari kedua kelas eksperimen telah normal dan homogen, maka selanjutnya dilakukan pengujian pada hipotesis 3 dengan menggunakan independent sample t-test. Berdasarkan perhitungan yang diperoleh dengan taraf signifikan $5 \%$, maka hasil dari $t_{\text {hitung }}=2,979$ dan $t_{\text {tabel }}=1,663$. Karena $t_{\text {hitung }}>t_{\text {tabel }}$ maka $H_{0}$ ditolak dan Ha diterima . Sehingga disimpulkan bahwa terdapat perbedaan efektivitas model pembelajaran ATI dan TAI terhadap hasil belajar siswa kelas VII SMPN 10 Batam.

Berdasarkan hasil perhitungan analisis data antara model pembelajaran ATI dan TAI sebagai variabel bebas dan hasil belajar matematika sebagai variabel terikat, maka diperoleh hasil yang menyatakan bahwa terdapat perbedaan efektivitas model pembelajaran ATI dan TAI terhadap hasil belajar siswa kelas VII SMPN 10 Batam. Hasil penelitian menunjukkan bahwa model pembelajaran ATI lebih efektif dari pada model pembelajaran TAI.

Pada pelaksanaannya model TAI tidak lebih efektif karena siswa masih belum terbiasa melakukan pembelajaran secara berkelompok. Selain itu, masih ada siswa yang masih enggan mengeluarkan pendapatnya saat diskusi sedang berlangsung. Materi pembelajaran yang diberikan pada akhir pertemuan juga menjadi penyebabnya. Biasanya siswa selalu diberikan 
penjelasan oleh guru, namun pada model pembelajaran TAI siswa dituntun mandiri dengan mencari sendiri materi yang akan dipelajari.

Sedangkan untuk model pembelajaran ATI lebih efektif karena dalam pelaksanaannya setiap kelompok diberikan perlakuan yang berbeda sesuai kemampuan kelompoknya. Selain itu pada kelompok kemampuan rendah lebih diberikan perlakuan khusus. Hal inilah yang menyebabkan motivasi belajar siswa menjadi lebih terpacu karena dengan adanya tutorial siswa merasa lebih terbimbing karena langsung diarahkan oleh guru. Maka dari itu hasil belajar yang diperoleh pun sesuai dengan harapan guru.

Di dalam pelaksanaan kedua model pembelajaran ini masih banyak ditemukan keterbatasan dan kendala. Salah satunya yaitu terbatasnya waktu penelitian yang menyebabkan kurang maksimalnya penerapan kedua model pembelajaran ini. Untuk kendala dalam penelitian ini yaitu masih kurangnya kesadaran siswa untuk belajar secara mandiri yang artinya dalam setiap pembelajaran siswa harus diarahkan oleh guru. Padahal kedua model pembelajaran ini sangat menuntut kemandirian siswa dengan cara belajar dengan teman anggota kelompoknya. Selain itu, sikap siswa yang masih malu dan tidak percaya diri untuk mengeluarkan pendapat juga menjadi salah satu kesulitan guru. Seharusnya tanpa diminta, siswa mau berinisiatif untuk berani mengeluarkan pendapatnya. Untuk mengatasi beberapa kendala dan kesulitan saat pembelajaran berlangsung, maka peneliti pun memberikan reward kepada siswa yang aktif agar siswa lebih termotivasi dan bersemangat untuk belajar.

\section{Kesimpulan Dan Saran}

Berdasarkan hasil penelitian yang telah dilakukan mengenai efektivitas model pembelajaran ATI dan TAI terhadap hasil belajar siswa kelas VII SMPN 10 Batam tahun ajaran 2016/2017, maka dapat disimpulkan bahwa pada taraf siginifikan 5\% yaitu:

a. Model pembelajaran ATI efektif terhadap hasil belajar siswa kelas VII SMPN 10 Batam.

b. Model pembelajaran TAI efektif terhadap hasil belajar siswa kelas VII SMPN 10 Batam.

c. Terdapat perbedaan efektivitas model pembelajaran ATI dan TAI terhadap hasil belajar siswa kelas VII SMPN 10 Batam.

Berdasarkan hasil penelitian dan penarikan kesimpulan, maka peneliti ingin memberi saran-saran yang selanjutnya dapat digunakan sebagai bahan masukan yang berguna untuk meningkatkan hasil belajar siswa. beberapa saran yang dapat peneliti berikan yaitu sebagai berikut kepada:

a. Agar kedepannya model pembelajaran ATI dan TAI dapat dijadikan alternatif dalam pembelajaran matematika agar siswa

b. Agar kedepannya bisa menggunakan dan menerapkan pembelajaran dengan menggabungkan suatu pendekatan dengan model pembelajaran.

c. Agar bisa melakukan penelitian lanjutan dengan menggunakan model pembelajaran ATI dan TAI yang tidak hanya melihat hasil belajar siswa, tetapi juga dapat melakukan penelitian lainnya dengan berbagai macam model pembelajaran yang ada.

\section{Daftar Pustaka}

Arikunto, Suharsimi. (2016). Prosedur Penelitian Suatu Pendekatan Praktik. Jakarta: Rineka Cipta. 
Depdiknas. (2003). Undang-Undang RI Nomor 20, Tahun 2003, Tentang Sistem Pendidikan Nasional.

Haris, Muhammad. (2015). "Penerapan Model Pembelajaran Team Assisted Individualization (TAI) Dalam Materi Pokok Matrik Dalam Meningkatkan Hasil Belajar Peserta Didik Kelas X IPA MA Nadlatusy Syubban Sayung Demak Tahun Pelajaran 2014/2015". Skripsi, tidak diterbitkan, Universitas Islam Negeri Walisongo Semarang. Semarang.

Heri Retnawati. (2016). Ananlisis Kuantitatif Instrumen Penelitian. Yogyakarta: Parama Publishing.

Lestari, Karunia Eka \& Yudhanegara, Mokhammad Ridwan. (2015). Penelitian Pendidikan Matematika. Bandung: Refika Aditama.

Lubis, S. (2013). Metotologi Penelitian Pendidikan. Padang: Sukabina Press.

Siahaan, Nirmasari. (2016). "Penerapan Model Pembelajaran Aptitude Treatment Interaction (ATI) untuk Meningkatkan Kemampuan Komunikasi Matematika Siswa”. Skripsi, tidak diterbitkan, Universitas Negeri Medan, Medan.

Slavin, Robert. E. (2005). Cooperative Learning: Teori, Riset dan Praktik. Bandung: Nusa Media.

Suwagsih, Erna \& Tiurlina. (2006). Model Pembelajara Matematika. Bandung: Wordpress.

Widiastuti, Wulan. (2014). "Pengaruh pembelajaran Aptitude Treatment Interaction (ATI) Terhadap Hasil Belajar Matematika Siswa". Skripsi. Tidak diterbitkan, Universitas Islam Negeri Syarif Hidayatullah. Jakarta. 